Original Paper http://ajol.info/index.php/ijbcs http://indexmedicus.afro.who.int

\title{
Effects of incorporation levels of Pueraria phaseoloides leaf flour on carcass characteristics and chemical composition of meat from local rabbit (Oryctolagus cuniculus) in South-East Gabon
}

\author{
Mamadou THIAM ${ }^{1}$, Gilbert Comlan ZOUGOU TOVIGNON ${ }^{1 *}$, \\ Abdourhamane Ibrahim TOURE ${ }^{1}$, Moussa KIMSE${ }^{2}$, Cédric SIMA OBIANG ${ }^{4}$, Arsène \\ Valery MBOKO ${ }^{1}$, Férence Ndzani MATUMUINI ${ }^{1}$, Frédéric Christol NGANSOP NONO ${ }^{3}$, \\ Louis Clément OBAME ENGONGA ${ }^{4}$, Joseph-Privat $\mathrm{ONDO}^{4}$, Fernand TENDONKENG ${ }^{5}$, \\ Emile MIEGOUE ${ }^{5}$, Benoit BOUKILA ${ }^{1}$ and Etienne PAMO TEDONKENG ${ }^{5}$ \\ ${ }^{1}$ National Higher Institute of Agronomy and Biotechnology (INSAB), University of Science and \\ Techniques Masuku (USTM), P.O. Box 941 Franceville, Gabon. \\ ${ }^{2}$ Animal Production Pole, UFR Sciences of Nature, Nangui Abrogoua University, 02 P.O. Box 801 \\ Abidjan 02, Côte d'Ivoire. \\ ${ }^{3}$ Technical School of Agriculture (TSA) Bambili, P.O. Box 15, Bambili (Bamenda), Cameroon. \\ ${ }^{4}$ Laboratory of Biochemistry, Faculty of Science of the University of Science and Techniques \\ Masuku (USTM), P.O. Box 941 Franceville, Gabon. \\ ${ }^{5}$ Laboratory of Animal Nutrition, Department of Animal Science, FASA, University of Dschang, \\ P.O. Box 222 Dschang, Cameroon. \\ *Corresponding author; E-mail: zougou.g@gmail.com
}

\begin{tabular}{ccc}
\hline Received: 15-01-2021 & Accepted: 22-06-2021 & Published: 30-06-2021 \\
\hline
\end{tabular}

\begin{abstract}
The objective of this study was to contribute in improving knowledge on rabbit feeding in Gabon. This work was conducted with the aim of studying carcass characteristics and chemical composition of meat from rabbit induced by feeds containing $P$. phaseoloides. To that effect, 20 young female rabbits from local breed, weighing averagely $611 \pm 33.20 \mathrm{~g}$ and aged about 6 weeks were randomly distributed in 4 groups of 5 animals each. The groups R0, R15, R20 and R25 were fed rations containing respectively $0 \%, 15 \%, 20 \%$ and $25 \%$ of $P$. phaseoloides. At the end of the trial, animals were slaughtered then eviscerated in order to evaluate carcass characteristics. Muscles were taken, ground and mixed for chemical analysis. No matter the ration, carcass characteristics showed no significant difference $(\mathrm{p}>0.05)$. Highest protein contents in meat were recorded in animals from R15 (23.90\% DM) and R20 (22.46\% DM). The lowest fat content (5.41\% DM) was that of animals from R25, followed by that from R20 (6.67\% DM). Based on these results obtained, the ration containing $20 \%$ Pueraria phaseolides (R20) could be recommended.

(C) 2021 International Formulae Group. All rights reserved.
\end{abstract}

Keywords: Rabbit, Pueraria phaseoloides, carcass, meat, chemical composition, South-East Gabon. 


\section{INTRODUCTION}

Food insecurity constitutes a major problem in Africa taking into consideration the imbalance between food availability and population growth (PNUD, 2012). The development of rabbit production (cuniculture) could contribute in the reduction of hunger and protein malnutrition in populations (Kouakou et al., 2016). Rabbit (Oryctolagus cuniculus) is a highly prolific species with a rapid growth. Its flesh is tender, tasty and nutritive and it presents dietary qualities with less fats and cholesterol (Djago et al., 2007). However, cuniculture faces many constraints among which there is improper feeding. One of the most important factors for the success and the economy of this livestock lies in feeding (Dahouda et al., 2013). Feeding represents 70\% of total production charges and the reduction of feed costs becomes an important preoccupation for animal keepers (Defang et al., 2014). Conventional protein sources become more and more scarce and expensive (Braine, 2008). In front of this situation, research on the valorization of alternative feed resources locally available could permit to improve the productivity of animals while mastering the costs of inputs (Ouédraogo et al., 2015). Many studies have been carried out on the incorporation of non-conventional local plant resources in the ration of animals (Ouedraogo et al., 2021). The use of local feeds rich in proteins and having no competition with humans such as Pueraria phaseoloides, appears as an alternative to commercial classical feeds (Aboh et al., 2002). In fact, Pueraria phaseoloides is a forage rich in fibers and a source of proteins available in tropical zone namely in Gabon. Its protein content varies between 18 and $21 \% \mathrm{DM}$ and its crude cellulose level varies between 34 and 43\% DM (Djago et al., 2007). This forage was subject to many studies on rabbit feeding in Africa (Akoutey et al., 2012 ; Kimsé et al., 2013). All these works showed no negative effect on animals. The objective of this research work was to study carcass characteristics and chemical composition of rabbit meat induced by feeds containing Pueraria phaseoloides.

\section{MATERIALS AND METHODS}

\section{Experimentation site}

The study was conducted from August to December 2018 at the National Higher Institute of Agronomy and Biotechnology (INSAB) of the University of Science and Techniques Masuku (USTM) in Franceville (Haut-Ogooué Province - Gabon). The climate is of equatorial type with two distinct seasons (dry and rainy). The mean annual temperature is $24.6{ }^{\circ} \mathrm{C}$ and the humidity level is $80 \%$. This zone is situated at a latitude of $1^{\circ} 37^{\prime} 59^{\prime \prime}$ ' south, a longitude of $13^{\circ} 35^{\prime} 00^{\prime \prime}$ ' and an altitude of 405 $\mathrm{m}$ above the sea level. The mean rainfall is 1803 mm/year (FDNS, 2004).

\section{Animal resources and housing}

In this study, 20 post-weaned female rabbits of local breed aged about 6 weeks with a mean live weight of $611 \pm 33.20 \mathrm{~g}$ were used. Animals were housed in individual metabolic cages with wire mesh, each measuring $50 \mathrm{~cm} \mathrm{x}$ $50 \mathrm{~cm}$ x $30 \mathrm{~cm}$. Each cage was equipped with a feeder and a drinker.

\section{Plant resources and conduct of trials}

Experimental feeds were made up of $P$. phaseoloides and other feed ingredients. The leguminous plant was harvested at the flowering stage, dried, crushed and then incorporated in different rations. Animals were distributed in 4 treatments (rations) of 5 animals (repetitions) per treatment. The 4 experimental rations (Table 1) were formulated by incorporating gradual levels of flour from $P$. phaseoloides. The ration R0 contained no $P$. phaseoloides while the rations $\mathrm{R} 15, \mathrm{R} 20$ and R25 contained $15 \%, 20 \%$ and $25 \%$ of flour from $P$. phaseoloides respectively. Each ration was randomly attributed to 5 animals in a factorial design during 7 weeks. Water was given ad libitum.

Samples of $100 \mathrm{~g}$ of each experimental ration was taken and dried at $60{ }^{\circ} \mathrm{C}$ till constant weight in a ventilated oven then crushed for chemical analyses. Weighing was done with the help of a digital balance of TEFAL brand mark (capacity $5 \mathrm{~kg}$ and precision $1 \mathrm{~g}$ ). At the end of the study, after a fasting period of 12 hours, the 5 animals of each treatment aged 13 
weeks, were weighed to determine mean values of live weights at slaughter. The animals were slaughtered and eviscerated for the evaluation of carcass characteristics.

The determination of the meat yield from the thigh was done by the dissection of the thigh in order to separate bone, muscle and adipose tissues. After obtaining the half carcass, part of the muscles (the majority from the thigh muscles of the rear part, the Longissimus muscle, the abdominal muscles of the saddle, the thoracic muscles and the front part of the scapular region) was taken according to experimental rations, then crushed and mixed with a meat crusher. $150 \mathrm{~g}$ of the mixture was taken for chemical analyses.

The chemical composition of $P$. phaseoloides and that of rations given to animals were determined in the Laboratory of Research in Biochemistry of the Faculty of Science at the USTM. Analysed parameters were: dry matter (DM) content (\%), crude proteins $(\mathrm{CB})$ level $(\%)$, crude cellulose (CC) level (\%) and fats content (\%). Three repetitions per sample were necessary to determine the mean value of each of these components. As far as rabbit meat is concerned, water, $\mathrm{CP}$, fats and ash contents were equally determined in the same laboratory. DM content was determined using the AOAC method (1990), the CP level using the Bradford/Sedmak method, the fats content using the extraction method with the help of the Soxhlet design and the CC using the Sheerer method.

\section{Statistical analysis}

Data on live weights at slaughter, carcass characteristics, weights and yields in organs, meat constitution and bone from the thigh and chemical composition of meat from rabbit were submitted to the analysis of variance at 1 factor (ration) using the SPSS 20.0 software. In case of significant differences between treatments, separation of means was done by the Duncan test at $5 \%$ significant level.

Table 1: Formulation and chemical composition of experimental rations and Pueraria phaseoloides.

\begin{tabular}{llllll}
\hline \multirow{2}{*}{ Ingredients (\%) } & \multicolumn{5}{c}{ Experimental rations } \\
\cline { 2 - 6 } & $\mathbf{R 0}$ & $\mathbf{R 1 5}$ & $\mathbf{R 2 0}$ & $\mathbf{R 2 5}$ & \\
\hline Corn & 44.9 & 44.9 & 44.9 & 44.9 & \\
Brewery wet grains & 12 & 6 & 5 & 2 & \\
CMA $V^{*}$ & 0.1 & 0.1 & 0.1 & 0.1 & \\
Soy flour (44) & 2 & 2 & 2 & 2 & \\
Pueraria phaseoloides leaves flour & 0 & 15 & 20 & 25 & \\
Cotton-seed cake & 9 & 7 & 5 & 4 & \\
Molass & 4 & 4 & 4 & 4 & \\
Wheat bran & 23 & 16 & 14 & 13 & 28.4 \\
Fish meal & 5 & 5 & 5 & 5 & 1.54 \\
Total & $\mathbf{1 0 0}$ & $\mathbf{1 0 0}$ & $\mathbf{1 0 0}$ & $\mathbf{1 0 0}$ & Pueraria phaseoloides \\
Chemical composition & & & & & 5.6 \\
Dry matter (\% FM) & 89.5 & 90.5 & 90.7 & 91.7 & 449 \\
Crude proteins (\% DM) & 16.7 & 16.3 & 16.0 & 15.9 & 15.6 \\
Fats (\% DM) & 2.44 & 0.71 & 0.98 & 2.5 & \\
Crude cellulose (\% DM) & 13.8 & 14.0 & 14.7 & 15.8 & \\
Ash (\% DM) & 5.11 & 4.06 & 5.20 & 4.56 & \\
Digestible energy (kcal/kg DM) & 2500 & 2466 & 2455 & 2392 & \\
DE/CP & 150 & 151 & 153 & 151 & \\
\hline CMA $V^{*}$ Complement of minerals, nitrogen (amino acids) and vitamins, DE: Digestible energy; CP: Crude proteins; FM: Fresh matter; \\
DM: Dry matter.
\end{tabular}




\section{RESULTS}

\section{Carcass characteristics}

Carcass characteristics of animals subjected to rations R0, R15, R20 and R25 showed no significant difference $(\mathrm{p}>0.05)$ (Table 2). However, the highest hot carcass yield $(81.36 \%)$ was recorded with animals receiving ration $\mathrm{R} 0$, followed by that of animals fed the ration R20 (80.77\%). The highest reference carcass yield $(48.84 \%)$ was recorded with animals receiving the ration $\mathrm{R} 15$, followed by that obtained with animals fed the ration R20 (47.35\%). It also appears that the highest yields of the front part and intermediate part (saddle) of the carcass, respectively $18.75 \%$ and $9.77 \%$, were recorded in animals fed the ration R15, followed by those animals subjected to the ration $\mathrm{R} 20$, respectively $18.64 \%$ and $9.36 \%$. Concerning the yield of the pelvic part of the carcass, the highest value $(19.19 \%)$ was recorded with animals fed the ration $\mathrm{R} 20$, followed by that of animals fed the ration $\mathrm{R} 15$ (19.02\%).

\section{Body organs and organs involved in digestion}

With the exception of the yields in sleeves, peri-renal fats, scapular fats, kidneys and skinless head of animals subjected to rations R0, R15, R20 and R25 which showed no significant difference $(\mathrm{p}>0.05)$, the skin and liver yields showed significant differences ( $\mathrm{p}<0.05$ ) between rations (Table 3). In fact, the skin yield in animals fed rations R15 and R20, respectively $12.89 \%$ and $13.30 \%$, were comparable $(p>0.05)$ between them, but both comparable ( $\mathrm{p}>0.05)$ on one hand, to that of animals subjected to the ration R0 (11.82\%) and on the other hand, comparable ( $\mathrm{p}>0.05$ ) to that of animals fed the ration R25 (13.96\%). However, the skin yield in animals fed the ration R25 was statistically higher $(\mathrm{p}<0.05)$ than that recorded in animals fed the ration $\mathrm{R} 0$. Otherwise, the liver yield in animals fed rations R20 and R25, respectively $2.88 \%$ and $2.85 \%$, were comparable $(\mathrm{p}>0.05)$ between them, but both were on one hand, comparable ( $\mathrm{p}>0.05$ ) to that of the animals subjected to the ration R0 $(3.22 \%)$ and on the other hand, comparable (p $>0.05)$ to that of animals fed the ration R15 $(2.59 \%)$. However, the liver yield in animals fed the ration R0 was statistically higher ( $\mathrm{p}<$ 0.05 ) than that recorded in animals fed with the ration $\mathrm{R} 15$.

\section{Thigh constitution}

The weight of the thigh, the weight of the thigh meat, the weight of thigh bone and the muscle/bone ratio in animals subjected to rations R0, R15, R20 and R25 showed no significant difference $(\mathrm{p}>0.05)$ (Table 4). However, the highest weight of the thigh $(144.00 \mathrm{~g})$ was obtained in rabbits subjected to the ration $\mathrm{R} 20$, this weight was followed by that of animals fed the ration R15 (134.33 g). Otherwise, the highest muscle/bone ratio (5.67) was recorded in animals fed rations R15 and R20.

\section{Chemical composition of the meat}

Water, fats, proteins and ash contents in meat from animals subjected to the rations $\mathrm{R} 0$, $\mathrm{R} 15, \mathrm{R} 20$ and R25 varied according to the incorporation level of $P$. phaseolides leaves (Table 5). The highest water content $(75.05 \%$ FM) was obtained with animals fed the ration $\mathrm{R} 25$, followed by that of the animals fed the ration R20 (74.40\% FM). On the other hand, lowest fats content $(5.41 \% \mathrm{DM})$ was recorded in animals receiving the ration $\mathrm{R} 25$, followed by that of animals fed the ration R20 (6.67\% DM). As far as ash content is concerned, the highest level was obtained in animals receiving the ration $\mathrm{R} 20$ ( $4.17 \% \mathrm{DM})$, followed by that of animals fed the ration R25 (4.04\% DM). The highest proteins level $(23.90 \%$ DM $)$ was recorded in animals fed the ration R15, followed by that recorded in those receiving the ration $\mathrm{R} 20$ (22.46\% DM). 
Table 2: Characteristics of carcass from local rabbit according to rations.

\begin{tabular}{|c|c|c|c|c|c|c|}
\hline \multirow{2}{*}{ Characteristics } & \multicolumn{4}{|c|}{ Rations } & \multirow[t]{2}{*}{ SEM } & \multirow[t]{2}{*}{ Prob. } \\
\hline & R0 & R15 & R20 & $\mathbf{R} 25$ & & \\
\hline Live weight at slaughter (g) & $1451.20^{\mathrm{a}}$ & $1493.80^{\mathrm{a}}$ & $1506.00^{\mathrm{a}}$ & $1462.00^{\mathrm{a}}$ & 86.20 & 0.996 \\
\hline Hot carcass (g) & $1174.20^{\mathrm{a}}$ & $1192.20^{\mathrm{a}}$ & $1217.80^{\mathrm{a}}$ & $1163.00^{\mathrm{a}}$ & 66.57 & 0.994 \\
\hline $\begin{array}{l}\text { Hot carcass yield (with head) } \\
(\%)\end{array}$ & $81.36^{\mathrm{a}}$ & $79.81^{\mathrm{a}}$ & $80.77^{\mathrm{a}}$ & $79.75^{\mathrm{a}}$ & 0.33 & 0.255 \\
\hline Cold carcass (g) & $1154.00^{\mathrm{a}}$ & $1174.00^{\mathrm{a}}$ & $1203.40^{\mathrm{a}}$ & $1153.20^{\mathrm{a}}$ & 66.57 & 0.994 \\
\hline Reference carcass (g) & $651.00^{\mathrm{a}}$ & $703.20^{\mathrm{a}}$ & $716.40^{\mathrm{a}}$ & $662.00^{\mathrm{a}}$ & 46.43 & 0.959 \\
\hline Reference carcass yield (\%) & $43.79^{\mathrm{a}}$ & $48.84^{\mathrm{a}}$ & $47.35^{\mathrm{a}}$ & $44.82^{\mathrm{a}}$ & 1.82 & 0.782 \\
\hline Front part of the carcass (g) & $243.00^{\mathrm{a}}$ & $269.60^{\mathrm{a}}$ & $280.80^{\mathrm{a}}$ & $261.20^{\mathrm{a}}$ & 16.98 & 0.900 \\
\hline Front part yield $(\%)$ & $16.47^{\mathrm{a}}$ & $18.75^{\mathrm{a}}$ & $18.64^{\mathrm{a}}$ & $17.75^{\mathrm{a}}$ & 0.72 & 0.693 \\
\hline Intermediate part (saddle) (g) & $139.00^{\mathrm{a}}$ & $139.60^{\mathrm{a}}$ & $142.40^{\mathrm{a}}$ & $138.00^{\mathrm{a}}$ & 11.92 & 0.999 \\
\hline $\begin{array}{l}\text { Intermediate part (saddle) } \\
\text { yield }(\%)\end{array}$ & $9.16^{\mathrm{a}}$ & $9.77^{\mathrm{a}}$ & $9.36^{\mathrm{a}}$ & $9.26^{\mathrm{a}}$ & 0.52 & 0.982 \\
\hline $\begin{array}{l}\text { Pelvic part (Rear of the } \\
\text { carcass) (g) }\end{array}$ & $267.60^{\mathrm{a}}$ & $272.20^{\mathrm{a}}$ & $290.60^{\mathrm{a}}$ & $261.80^{\mathrm{a}}$ & 19.45 & 0.966 \\
\hline Pelvic part yield (\%) & $18.04^{\mathrm{a}}$ & $19.02^{\mathrm{a}}$ & $19.19^{\mathrm{a}}$ & $17.72^{\mathrm{a}}$ & 0.80 & 0.910 \\
\hline
\end{tabular}

a: means bearing the same letters on the same line are not significantly different at 5\% level; R0, R15, R20 and R25: 0\%, 15\%, $20 \%$ and $25 \%$ of incorporation levels of Pueraria phaseoloides in rations respectively; SEM: Standard Error on the Mean; Prob.: Probability (5\%).

Table 3: Weight and yield of some body organs and those involved in the digestion in local rabbit according to rations.

\begin{tabular}{|c|c|c|c|c|c|c|}
\hline \multirow{2}{*}{ Characteristics } & \multicolumn{4}{|c|}{ Rations } & \multirow[t]{2}{*}{ SEM } & \multirow[t]{2}{*}{ Prob. } \\
\hline & R0 & R15 & $\mathbf{R 2 0}$ & $\mathbf{R} 25$ & & \\
\hline Skin (g) & $177.00^{\mathrm{a}}$ & $192.60^{\mathrm{a}}$ & $200.20^{\mathrm{a}}$ & $208.20^{\mathrm{a}}$ & 13.80 & 0.893 \\
\hline Skin yield (\%) & $11.82^{\mathrm{b}}$ & $12.89^{\mathrm{ab}}$ & $13.30^{\mathrm{ab}}$ & $13.96^{\mathrm{a}}$ & 0.28 & 0.037 \\
\hline Sleeves $(\mathrm{g})$ & $45.80^{\mathrm{a}}$ & $48.00^{\mathrm{a}}$ & $46.80^{\mathrm{a}}$ & $45.60^{\mathrm{a}}$ & 1.93 & 0.976 \\
\hline Sleeves yield (\%) & $3.26^{\mathrm{a}}$ & $3.25^{\mathrm{a}}$ & $3.16^{\mathrm{a}}$ & $3.19^{\mathrm{a}}$ & 0.07 & 0.960 \\
\hline Peri-renal fats (g) & $14.60^{\mathrm{a}}$ & $14.00^{\mathrm{a}}$ & $11.40^{\mathrm{a}}$ & $12.80^{\mathrm{a}}$ & 2.29 & 0.969 \\
\hline Peri-renal fats yield (\%) & $1.03^{\mathrm{a}}$ & $1.09^{\mathrm{a}}$ & $0.91^{\mathrm{a}}$ & $1.05^{\mathrm{a}}$ & 0.13 & 0.974 \\
\hline Scapular fats (g) & $4.00^{\mathrm{a}}$ & $3.60^{\mathrm{a}}$ & $4.40^{\mathrm{a}}$ & $3.40^{\mathrm{a}}$ & 0.71 & 0.968 \\
\hline Scapular fats yield (\%) & $0.29^{\mathrm{a}}$ & $0.30^{\mathrm{a}}$ & $0.32^{\mathrm{a}}$ & $0.27^{\mathrm{a}}$ & 0.04 & 0.979 \\
\hline Kidneys (g) & $8.20^{\mathrm{a}}$ & $8.00^{\mathrm{a}}$ & $8.60^{\mathrm{a}}$ & $8.40^{\mathrm{a}}$ & 0.33 & 0.941 \\
\hline Kidneys yield (\%) & $0.57^{\mathrm{a}}$ & $0.54^{\mathrm{a}}$ & $0.58^{\mathrm{a}}$ & $0.59^{\mathrm{a}}$ & 0.01 & 0.652 \\
\hline Liver (g) & $45.20^{\mathrm{a}}$ & $37.40^{\mathrm{a}}$ & $43.40^{\mathrm{a}}$ & $42.00^{\mathrm{a}}$ & 2.41 & 0.730 \\
\hline Liver yield (\%) & $3.22^{\mathrm{a}}$ & $2.59^{\mathrm{b}}$ & $2.88^{\mathrm{ab}}$ & $2.85^{\mathrm{ab}}$ & 0.09 & 0.004 \\
\hline Skinless head (g) & $91.00^{\mathrm{a}}$ & $95.00^{\mathrm{a}}$ & $101.60^{\mathrm{a}}$ & $88.40^{\mathrm{a}}$ & 4.04 & 0.712 \\
\hline Skinless head yield (\%) & $6.47^{\mathrm{a}}$ & $6.45^{\mathrm{a}}$ & $6.81^{\mathrm{a}}$ & $6.20^{\mathrm{a}}$ & 0.14 & 0.524 \\
\hline
\end{tabular}

$\mathrm{a}$ et $\mathrm{b}$ : means bearing the same letters on the same line are not significantly different at $5 \%$ level ; R0, R15, R20 and R25 $0 \%, 15 \%, 20 \%$ and $25 \%$ of incorporation levels of Pueraria phaseoloides in rations respectively ; SEM : Standard Error on the Mean ; Prob. : Probability (5\%). 
Table 4: Meat and bone constitution of the thigh in local rabbit according to rations.

\begin{tabular}{|c|c|c|c|c|c|c|}
\hline \multirow{2}{*}{ Characteristics } & \multicolumn{4}{|c|}{ Rations } & \multirow[t]{2}{*}{ SEM } & \multirow[t]{2}{*}{ Prob. } \\
\hline & R0 & $\mathrm{R} 15$ & $\mathrm{R} 20$ & $\mathrm{R} 25$ & & \\
\hline Thigh weight (g) & $130.33^{\mathrm{a}}$ & $134.33^{\mathrm{a}}$ & $144.00^{\mathrm{a}}$ & $126.00^{\mathrm{a}}$ & 12.65 & 0.975 \\
\hline Meat weight from the thigh (g) & $110.00^{\mathrm{a}}$ & $114.00^{\mathrm{a}}$ & $122.67^{\mathrm{a}}$ & $102.33^{\mathrm{a}}$ & 11.78 & 0.959 \\
\hline Bone weight from the thigh (g) & $20.33^{\mathrm{a}}$ & $20.33^{\mathrm{a}}$ & $21.33^{\mathrm{a}}$ & $23.67^{\mathrm{a}}$ & 1.17 & 0.774 \\
\hline Muscle/bone ratio & $5.33^{\mathrm{a}}$ & $5.67^{\mathrm{a}}$ & $5.67^{\mathrm{a}}$ & $4.33^{\mathrm{a}}$ & 0.45 & 0.743 \\
\hline
\end{tabular}

Table 5: Chemical composition of meat from local rabbit according to rations.

\begin{tabular}{lcccc}
\hline \multirow{2}{*}{\multicolumn{1}{c}{ Characteristics }} & \multicolumn{3}{c}{ Rations } \\
\cline { 2 - 5 } & R0 & R15 & R20 & R25 \\
\hline Water content (\% FM) & 73.51 & 72.70 & 74.40 & 75.05 \\
Fats content (\% DM) & 12.34 & 11.17 & 6.67 & 5.41 \\
Proteins content (\% DM) & 20.96 & 23.90 & 22.46 & 20.36 \\
Total ash content (\% DM) & 3.82 & 3.61 & 4.17 & 4.04 \\
\hline
\end{tabular}

R0, R15, R20 and R25: 0\%, 15\%, 20\% and 25\% of incorporation levels of Pueraria phaseolides in the rations respectively; MF: fresh matter; DM: dry matter.

\section{DISCUSSION}

\section{Carcass characteristics, body organs and digestive organs}

Carcass characteristics of animals subjected to rations $\mathrm{R} 0, \mathrm{R} 15, \mathrm{R} 20$ and $\mathrm{R} 25$ showed no significant difference $(\mathrm{p}>0.05)$. However, the highest slaughter live weight $(1506 \mathrm{~g})$ was obtained with rabbits fed the ration $\mathrm{R} 20$. This value is higher than that of $1422.12 \mathrm{~g}$ reported by Nawel (2007), but lower than that recorded by Lebas (2015) (2376 g). This difference could be explained by the chemical composition of the ration, by the constitution of the diet and by the slaughter age of the animals. In fact, according to Zougou's investigations (2017), the protein level in the ration influences the slaughter weight and the carcass weight. The same observations were reported by Zougou (2012) who observed a variation in live weight at slaughter and in carcass weight with head, by including fresh Tithonia diversifolia leaves in animals' rations. On the other hand, Nawel's works (2007) reported a low live weight at slaughter
$(1422.12 \mathrm{~g})$ in rabbits aged 84 days versus a high weight $(2125.0 \mathrm{~g})$ in those aged 224 days.

In the present study, the highest hot carcass yield $(81.36 \%)$ was obtained with animals subjected to the ration $\mathrm{R} 0$, followed by that recorded in rabbits fed the ration $\mathrm{R} 20$ $(80.77 \%)$. These results are higher than that reported by Nawel (2007) $(67.15 \%)$. On the other hand, the highest reference carcass yield $(48.84 \%)$ was obtained with animals subjected to the ration $\mathrm{R} 15$ followed by that recorded in animals fed the ration R20 (47.35\%); these values are lower than those reported by Nawel (2007), Abida Ouyed (2009) and Lebas (2015), respectively $53.81 \%, 51.32 \%$ and $56.60 \%$. The highest yields of the front and intermediate carcass, respectively $18.75 \%$ and $9.77 \%$, were obtained in the present study with animals fed the ration $\mathrm{R} 15$. These values were followed by those obtained in rabbits fed the ration R20, respectively $18.64 \%$ and $9.36 \%$. These results are lower than those reported by Lebas (2015) on one hand (31.69\% and $17.13 \%$ respectively) and, on the other hand, than those recorded by Abida Ouyed (2009) (29.88\% and 28.44\% 
respectively). Moreover, in this study, the highest yield in the pelvic part (19.19\%) was obtained in animals fed the ration R20. This value is lower than those reported by Lebas (2015) and Abida Ouyed (2009), respectively $31.15 \%$ and $35.74 \%$.

The highest muscle/bone ratio (5.67) was recorded in animals fed rations R15 and R20. This result is comparable to that of 5.87 reported by Lebas (2015), but higher than those recorded by Nawel (2007) and Abida Ouyed (2009) (respectively 4.38 and 4.83). In the present study, the lowest yield in peri-renal fats $(0.91 \%)$ was recorded with animals subjected to the ration R20 and that of the lowest scapular fats $(0.27 \%)$ in animals fed the ration R25. These results are lower than those reported by Nawel (2007) who obtained $1.70 \%$ of peri-renal fats and $0.74 \%$ of scapular fats. These differences could be explained by the type of feed, the slaughter weight, the age of the animals and the breed. In fact, research works carried out by Selmi et al., (2010) revealed that the addition of the yeast Saccharomyces cereviciae in the ration could improve on the carcass yield in lambs. Thus, it has been noticed that carcass weight recorded in supplemented animals $(8.46 \mathrm{~kg})$ was higher than that of animals without supplementation $(7.97 \mathrm{~kg})$. The increase in feeding during the finishing phase leads to an increase in slaughter live weight, in carcass weight and in carcass yield (Miégoué, 2016). On the other hand, research works conducted by Zougou (2012) revealed that the slaughter live weight is significantly $(p>0.05)$ correlated to carcass yields and that, those parameters are influenced by feeding. Investigations from Heyer and Lebret (2006) showed that the increase in the age at slaughter goes hand in hand with the improvement in carcass yield. Concerning the breed, Liviu (2005) noticed that, carcass weight was higher in hybrid lambs $(15.7 \mathrm{~kg})$ than in homozygotes $(13.2 \mathrm{~kg})$.

\section{Chemical composition of meat}

The meat with highest water content in this study was obtained in animals subjected to the ration R25 (75.05\%). This result is higher than those reported by Nawel (2007) and
Combes (2004), respectively $72.25 \%$ and $73.5 \%$; but close to that obtained by Tandzong et al. (2015) (74.31\%) in cavies fed a ration containing $8 \%$ of cassava leaves. However, it was lower than that reported by Zougou (2017) and Tandzong et al. (2015), respectively $92.00 \%$ in cavies fed a ration containing $14 \%$ DM of CP and $77.79 \%$ in cavies fed a ration containing $10 \%$ of cassava leaves. This difference could be justified by the la chemical composition of rations, the animal species, the breed, the sex and the type of muscle. In fact, the chemical composition of meat varies according to rations (Tandzong et al., 2015; Mweugang, 2016) and according to the level of $\mathrm{CP}$ in the ration (Zougou, 2017). On the other hand, research works from Tandzong et al., (2015) revealed that the water content in male muscles was higher $(70.45-73.23 \%)$ than in females (65.56-73.23\%). Moreover, research works from Tandzong et al. (2015) highlighted that the water content in thigh muscles was higher $(72.31 \%)$ than in the loin $(70.89 \%)$ and in the shoulder (69.77\%). The same observation was made by Zougou (2017) who noticed that the water content in thigh muscles was higher $(90.00 \%)$ than that of the loin $(89.83 \%)$ and that of the shoulder $(83.33 \%)$. Investigations from Combes (2004) showed a water content of $69.1 \%$ in calf meat and $72.2 \%$ in chicken.

The lowest fat content in meat in this study (5.41\% DM) was obtained in animals fed the ration $\mathrm{R} 25$, followed by that of animals fed the ration $\mathrm{R} 20(6.67 \% \mathrm{DM})$. These values are close to those obtained by Combes (2004) (5\%), but higher than those reported by Nawel (2007) (3.47\%). This difference could be explained by the age at slaughter, the sex and the meat slice. In fact, the mean fats content in rabbit meat is $5 \mathrm{~g} / 100 \mathrm{~g}$, however according to the metabolic type, the anatomical location or the function of the muscles, fats content in muscles varies from 0.9 to $5 \mathrm{~g} / 100 \mathrm{~g}$ (Nawel, 2007). Fats content in muscles increases with age and the weight of animals (Heyer and Lebret, 2006). According to the same authors, when the body weight increases from birth to slaughter, variations in carcass composition are 
observed. Moreover, the increase in slaughter weight leads to a decrease in muscles and bones proportions, and increase in the proportion of fats in the carcass. Research findings from Tandzong et al. (2015) and Zougou (2017), revealed that in a same animal, fats content can vary according to the muscle type. The sex of the animal induces different body compositions (Zougou, 2017). According to this author, females have a lower growth potential than that of entire males, but the development of adipose tissues is more rapid. Thus, with the same live weight, females have a high fat deposition in adipose tissues than males (Tandzong et al., 2015 ; Zougou, 2017). The highest fats content in female muscles could be explained by hormone effects such as oestrogens (Hottin et al., 2019). In fact, oestrogens stimulate fats distribution in the pelvic cavity and in thigh.

Highest proteins contents in this study were recorded in animals fed the ration R15 $(23.90 \%)$. This value is higher than that reported by Combes (2004) and Nawel (2007) $(22.19 \%)$. The crude proteins in the ration, the age and the muscle type could justify this difference. In fact, investigations from Zougou (2017) revealed that the chemical composition of cavy meat varied according to the level of proteins in the ration. This author reported proteins levels of $18.50 \%, 17.00 \%$ and $19.00 \%$ in the meat of animals receiving rations containing respectively $14 \%, 16 \%$ and $18 \%$ of CP. On the other hand, Nawel's investigations (2007) revealed proteins levels of $18.2 \%$, $20.2 \%$ and $22.19 \%$ in rabbits aged respectively 30,70 and 84 days. Research works of Tandzong et al. (2015) showed that, proteins level in thigh was higher (18.39\% DM) than that of the loin $(18.35 \% \mathrm{DM})$ and of the shoulder (17.34\% DM); the same observation was made by Zougou (2017).

The highest ash content in meat in this study $(4.17 \%)$ was obtained with animals fed the ration R20. This value is higher than those reported by Nawel (2007) and Combes (2004), respectively $1.28 \%$ and $1.2 \%$. This difference could be related to the feeding and animal species.

\section{Conclusion}

At the end of this study, it emerges globally that, the incorporation of Pueraria phaseoloides in rabbit feeding had no influence on carcass characteristics. On the other hand, the chemical composition of meat varied according to the incorporation level of $P$. phaseoloides leaves. Based on these results obtained, the ration containing $20 \%$ of $P$. phaseoloides (R20) could be recommended. However, it would be desirable to continue this study over a long period in order to better assess carcass characteristics and the chemical composition of rabbit meat.

\section{COMPETING INTERESTS}

The authors declare that they have no competing interests.

\section{AUTHORS' CONTRIBUTIONS}

GCZT designed, set up the experimental design, participated in the conduct of trials and wrote the manuscript ; AIT participated in setting up the experimental design and in the conduct of trials as well as in the critical reading of the manuscript ; FNM, AVM participated in the revision of the manuscript and the scientific assistance in the realization of this work; MT set up the experimental design, conducted the trials, conducted all laboratory analyzes under the guidance of LCOE and collected the data ; MK, CSO, LCOE, J-PO, FCNN, FT, EM participated in the technical and scientific assistance of the work as well as in the critical reading of the manuscript; $\mathrm{BB}$ and EPT coordinated and guided the technical and scientific realization of the work.

All the authors have read and approved this version of the work.

\section{ACKNOWLEDGEMENTS}

We sincerely thank the National Higher Institute of Agronomy and Biotechnology (INSAB), University of Science and 
Techniques Masuku (USTM) to have financed this study.

\section{REFERENCES}

Abida O. 2009. Evaluation of yields in carcass, in muscle and in weight of different parts of homozygote and hybrid rabbits. Financial support programme to associations of breeders designated by the ministry of agriculture, fisheries and feeding in Quebec.

Aboh AB, Olaafa M, Dossou-Gbété GSO, Dossa AD, Djagoun N. 2002. Voluntary ingestion and apparent digestibility of a ration based on Mucuna pruriens var. utilis seeds flour completed with forage in rabbits. Tropicultura, 20(4): 165-169. DOI:

http://www.tropicultura.org/text/v20n4.p df

Akoutey A, Kpodekon MT, Bannelier C, Gidenne T. 2012. Zootechnical performance of young rabbits receiving granulated feeds containing Pueraria phaseolides. Tropicultura, 30(3) : 161166.

DOI:

http://www.tropicultura.org/text/v30n3/1 61.pdf

AOAC (Association of Official Analytical Chemist). 1990. Official Method of Analysis $\left(15^{\text {th }}\right.$ edition). AOAC: Washington D.C; $10 \mathrm{p}$.

Braine A. 2008. The point on rabbit market in France. A sector in crisis. Cuniculture Magazine, 35: 60-67. DOI: https://www.doi.10.3390/foods9050654

Combes S. 2004. Nutritional value of rabbit meat. INRA. Prod. Anim, 17(5): 373-383. http://www.inra.fr/internet/produits/pa/n ew.htm

Dahouda M, Adjolohoun S, Senou M, Toleba SS, Abou M, Vidjannagni DS, Kpodekon M, Youssao AKI. 2013. Effets des aliments contenant les folioles de Moringa oleifera Lam et des aliments commerciaux sur les performances de croissance des lapins (Oryctolagus cuniculus) et la qualité de la viande. Int.
J. Biol. Chem. Sci., 7(5): 1838-1852. DOI: 10.4314/ijbcs.v7i5.5

Defang HF, Keambou TC, Manjeli Y, Teguia A, Pamo TE. 2014. Influence de la farine des feuilles de Leucaena leucocephala sur les performances de croissance des lapereaux. Int. J. Biol. Chem. Sci., 8(4): 1430-1437. DOI: $10.4314 /$ ijbcs.v8i4.7

Djago A, Yaou Kpodekon M. 2007. Complete guide of rabbit keeper in tropical zone. corronsac: Association "Cuniculture".

FDNS. 2004. Information for MSKU as of August 2004. www.fdns.org.

Heyer A, Lebret B. 2006. Compensatory growth in pig: Effects on growth performance, carcass composition and meat quality. Pig Research Days, 38: 7380.

Hottin C, Simoneau B, Le Stunff H. 2019. Lipid regulation by thyroid hormones. Med Sci (Paris), 35: 271-274. DOI: https://doi.org/10.1051/medsci/2019045

Kimsé M, Soro D, Bleyeré NM, Yapi JN, Fantodji A. 2013. Apport d'un fourrage vert tropical, Centrosema pubescens, en complément au granulé : effet sur les performances de croissance et sanitaire $\mathrm{du}$ lapin (Oryctolagus cuniculus). International Journal of Biological and Chemical Sciences, 7(3): 1234-1242. DOI: 10.4314/ijbcs.v7i3.29

Kouakou N'G.DV, Kouba M, Thys E. 2016. Comparative study of the in vivo digestibility of the Guinea grass (Panicum maximum Jacq.) associated to leaves and stems of the sweet potato (Ipomea batatas (L.) Lam) (Panipo diet) or to the milk grass (Euphorbia heterophylla L.) (Paneuph diet) in rabbit (Oryctolagus cuniculus L.) and Guinea pig (Cavia porcellus L.). Tropicultura, 34(2): $\quad$ 158-165. DOI: http://www.tropicultura.org/text/v34n2/1 58.pdf

Lebas F. 2015. Growth and carcass quality of rabbit meat from three crossed genoypes fed 2 types of feed and slaughtered at fix live weight. Cuniculure $\mathrm{p} 175$. 
Liviu D. 2005. Influence of the breed, the sex and the slaughter weight on the quality of meat from loud lamb. Laval University, pp 11-12.

Miégoué E. 2016. Three leguminous forages (Arachis glabrata, Calliandra calothyrsus or Desmodium intortum) as proteins sources associated to two grasses (Pennisetum purpureum and Panicum maximum) in Guinea pig (Cavia porcellus L.) fedding. Doctorate $(\mathrm{PhD})$ thesis in Biotechnology and Animal Production. University of Dschang. 158p.

Mweugang NN. 2016. Utilization of cassava (Manihot esculenta Crantz) leaves as alternative source of proteins on production performance of Guinea pig (Cavia porcellus L.) and chemical composition of its meat. Doctorate $(\mathrm{PhD})$ thesis in Biotechnology and Animal Production. University of Dschang. 166p.

Nawel N. 2007. Morphological characteristics of local rabbit. Dissertation as partial fulfilment for the award of Veterinarian diploma, University EL-Hadj LAKHDAR- BATNA.

Ouédraogo B, Balé B, Zoundi SJ, Sawadogo L. 2015. Caractéristiques de l'aviculture villageoise et influence des techniques d'amélioration sur ses performances zootechniques dans la province du Sourou, région Nord-Ouest Burkinabè. Int. J. Biol. Chem. Sci., 9(3): 1528-1543. DOI:

http://dx.doi.org/10.4314/ijbcs.v9i3.34.

Ouédraogo B, Nikiema ZS, Zoundi JS, Sawadogo L. 2021. Effets de l'incorporation de la biomasse d'azolla (Azolla pinnata) séchée dans les rations $\mathrm{du}$ poulet en aviculture traditionnelle améliorée. International Journal of Biological and Chemical Sciences, 15(1):
212-223.

DOI:

https://dx.doi.org/10.4314/ijbcs.v15i1.1.

United Nations Programme for Development (PNUD). 2012. Report on the human development in Africa. Towards a sustainable food security. Edition and Production: Communications Development Incorporated, Washington, DC, USA.

Selmi H, Manel BK, Rekik B, Ben Gara Q, Hammami M, Rouissi H. 2010. Effect of the incorporation of the yeast Saccharomyces cerevisiae (BIOSAF Sc. 47) in the concentrate on the growth perfomance and the quality of carcass in lambs from Sicilo-Sarde breed. Livestock Rechearch for Rural Developpement, 22(1): 7-10. DOI: http://www.1rrd.org/1rrd22/1/cont2201.h $\mathrm{tm}$.

Tandzong MLC, Mbougueng PD, Womeni HM, Mweugang NN. 2015. Effect of cassava (Manihot esculenta) leaf level in Guinea pig (Cavia porcellus) meal on the physico-chemical and technological properties of its meat. Scientific Rechearch Publishing. Food and Nutrition Sciences, 6: 1408-1421. DOI: http://www.scirp.org/journal/fns.

Zougou TCG. 2012. Effect of different supplementation levels of Tithonia diversifolia leaves on growth performance and carcass characteristics in Guinea pig (Cavia porcellus). Master of Science thesis. University of Dschang. $75 \mathrm{p}$.

Zougou TCG. 2017. Proteins requirements and production performance of Guinea pig (Cavia porcellus L.) in West Cameroon. Doctorate $(\mathrm{PhD})$ thesis. University of Dschang. 181p. 